University of Nebraska - Lincoln

DigitalCommons@University of Nebraska - Lincoln

Agronomy \& Horticulture -- Faculty Publications

Agronomy and Horticulture Department

3-1939

\title{
Major Changes in Grassland as a Result of Continued Drought
}

J. E. Weaver

University of Nebraska-Lincoln

F. W. Albertson

University of Nebraska-Lincoln

Follow this and additional works at: https://digitalcommons.unl.edu/agronomyfacpub

Part of the Plant Sciences Commons

Weaver, J. E. and Albertson, F. W., "Major Changes in Grassland as a Result of Continued Drought" (1939). Agronomy \& Horticulture -- Faculty Publications. 448.

https://digitalcommons.unl.edu/agronomyfacpub/448

This Article is brought to you for free and open access by the Agronomy and Horticulture Department at DigitalCommons@University of Nebraska - Lincoln. It has been accepted for inclusion in Agronomy \& Horticulture -Faculty Publications by an authorized administrator of DigitalCommons@University of Nebraska - Lincoln. 


\title{
MAJOR CHANGES IN GRASSLAND AS A RESULT OF CONTINUED DROUGHT ${ }^{\mathrm{I}}$
}

\author{
J. E. WEAVER AND F. W. ALBERTSON
}

(WITH NINE FIGURES)

\section{Introduction}

A comprehensive research on I35 large tracts of prairie was completed in 1933 after five years of study. These tracts were distributed over an area of 60,000 square miles, including the eastern one-third of Nebraska, the western one-third of Iowa, and adjacent areas in the four neighboring states (2). This investigation furnished the background for an understanding of the profound changes which have occurred during the several years of the great drought, which first became pronounced in I934. The response of prairie to the drought of that year has been discussed (3). Likewise, a detailed account of the destruction caused by the drought years of I934 and I935 and resultant changes and shifting of populations in both true and mixed prairies have been recorded (I).

Research has been continued from season to season throughout the long period of abnormally low rainfall. Continuous records of climatic and edaphic factors have been obtained, and changes in behavior and structure of vegetation intensively studied. These have been recorded in detail by means of scores of permanent quadrats scattered widely from eastern Nebraska to western Kansas. With successive years of drought further deterioration has occurred. Favorable precipitation during the spring and early summer of 1938 (and during 1937 in certain portions of the area) has brought about important early stages in recovery. Several years with normal or excess precipitation, however, must intervene before the general trends toward readjustment are clearly seen. The purpose of the present paper is to summarize some of the more important changes which have occurred since 1935 .

I Contribution no. I Io from the Department of Botany, University of Nebraska. 


\section{Observations}

\section{DECREASE IN PERENNIAL GRASSES}

Among the most striking effects of the drought is the very great depletion of the formerly most important regional dominant, little bluestem (Andropogon scoparius). In numerous prairies not a trace remains; in others small amounts persisted, usually only in the most favorably moist habitats (figs. I, 2, 3). This loss has been general in true prairie of the southern half of Nebraska. In Iowa this grass has generally persisted but sometimes with a shifting in importance from first to third place, being outranked by Sporobolus heterolepis and Andropogon furcatus. Since this species alone frequently occupied 50 to more than 70 per cent of the total basal cover on uplands, its death has left open great areas for invasion.

The loss of Indian grass (Sorghastrum nutans) has been similar to that of little bluestem. Its nearly complete disappearance is much less noticeable, however, since it formerly constituted only about 2 per cent of the basal cover of vegetation.

The death of Kentucky bluegrass (Poa pratensis) has been general in pastures, where it often had nearly complete control, but was somewhat less in prairie because of the shade afforded by mid grasses and forbs. While many prairie areas (especially westward) are practically free of this invader, which normally furnished 5 to 9 per cent of the basal cover on uplands and lowlands respectively, in others it occurs commonly in ravines and at the bases of north slopes. During the favorable season of 1938 , these relict patches produced a fine crop of seed and also spread rapidly vegetatively.

That the tall grass, Andropogon furcatus, should persist in mixtures where the mid grass, $A$. scoparius, died seems anomalous, but the reason is readily explainable. As the soil moisture became depleted from above downward, little bluestem succumbed when its root system, which is usually about 4 feet deep, had exhausted the available moisture to this depth. The larger and more deeply rooted big bluestem, although much desiccated, persisted. But since the light rainfall of the following years did not add to the scant supply of subsoil moisture, the big bluestem also often succumbed. Its decrease in abundance in $1936-37$ has been repeatedly recorded. Thus 


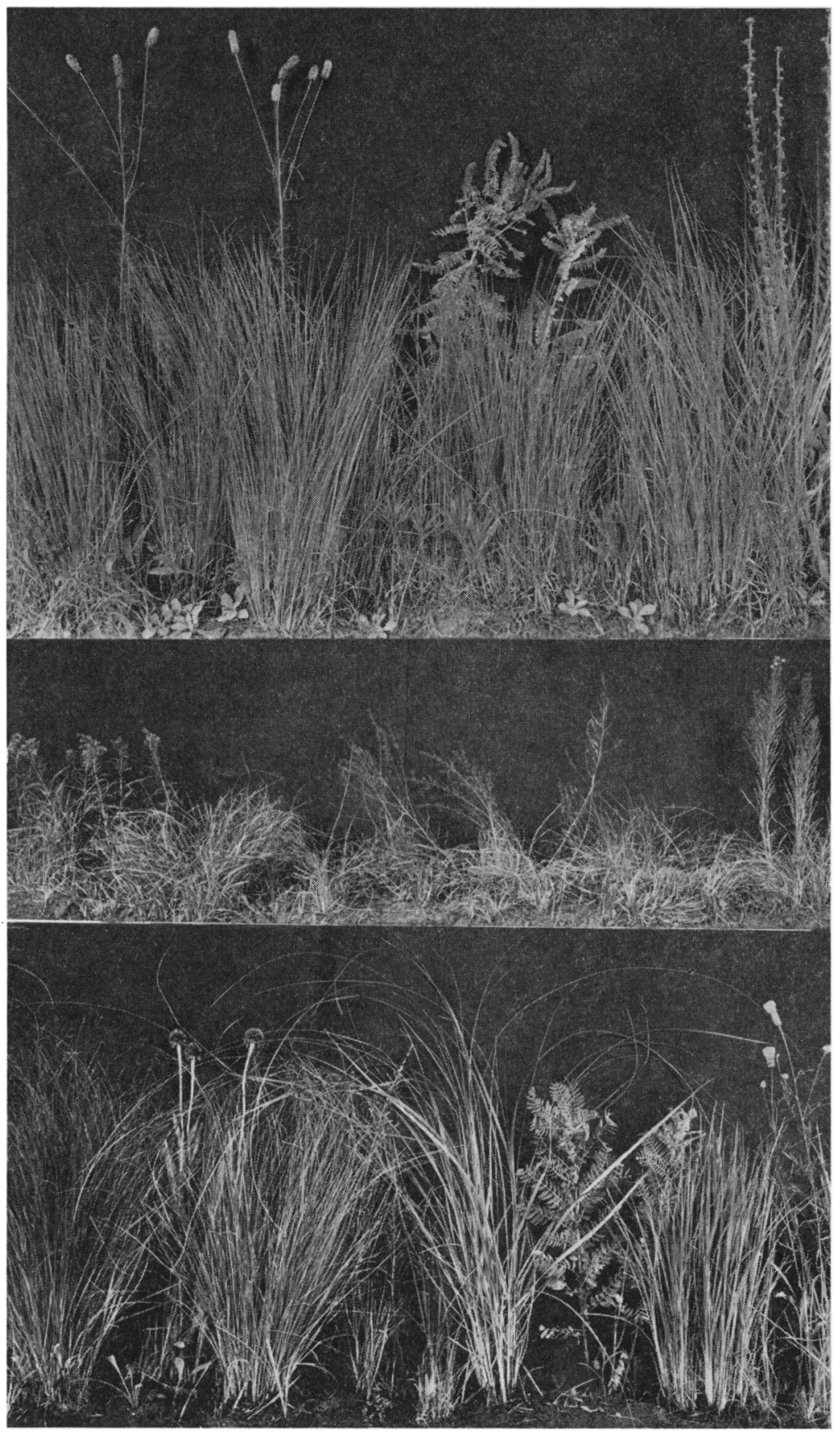

FIGS. I-3.-Upland little-bluestem prairie at Lincoln, Neb., early in August in the same square rod but during different years: Fig. I, normal stand in 1932 of Andropogon scoparius 18 inches tall. Note lower story of Antennaria campestris and Panicum scribnerianum, and upper one of Petalostemon candidus (left), Amorpha canescens, and Liatris scariosa. Fig. 2, dried bluestem in 1934 only 5 to 6 inches tall and forbs about half normal height. Solidago glaberrima (left), Aster multiflorus, and Liatris punctata. Fig. 3, remaining bluestem (right) in 1938 , I 2 inches tall; rest has been replaced by $S$ porobolus heterolepis (bunches on left) and Stipa spartea (center). Forbs are Echinacea pallida (left), Amorpha canescens, and Petalostemon candidus. Note wide spacing of grasses, complete disappearance of lower layer, and bareness of soil. 
over large areas in certain prairies now occupied by needle grass (Stipa spartea) or other xeric species, big bluestem has largely vanished from the upland just as little bluestem disappeared during the earlier years of the drought. But this vigorous species, never entirely routed from the uplands, where it formerly constituted as much as I 5 per cent of the basal cover, made a remarkable growth during 1938. Having much moist, rich soil with little competition, it reached a height and stem diameter otherwise attained only on lowlands, flowered profusely, and spread rapidly by means of strong rhizomes. It is thus claiming much territory formerly occupied by little bluestem, with which it was so regularly intermixed.

\section{GENERAL DECREASE OF FORBS}

The recurrence of years with minimum rainfall has resulted in great decrease of most species of forbs. This pertains to those that root deeply as well as to those of moderate and shallower rooting habit. Some evidence has been obtained that certain species persisting on subsoil moisture at depths below 4 or 5 feet extended their roots even more deeply. But although moisture below the solum was continuous to great depths, repeated sampling showed that it existed only in small amounts. Throughout the drought years rainfall did not augment the supply. Consequently the roots of most individuals came in contact with only definitely limited amounts of deep soil moisture, and many were poorly fitted to profit from water occasionally furnished by rainfall to the surface soil. These conditions, often coupled with desert-like environment aboveground, readily account for the death of increasing numbers of forbs. Astragalus crassicarpus, Psoralea floribunda, Helianthus rigidus, and Kuhnia glutinosa furnish examples of the general situation. Their disappearance was much more gradual and later than that of the shallowly rooted Fragaria virginiana, Antennaria campestris, and others, which were nearly swept away during the first year. To appreciate fully the paucity of forbs one needs only to examine the prairies eastward across the Missouri River, where they maintained almost their usual abundance. Elsewhere, with exceptions to be noted, losses have been approximated at one-half to two-thirds. 


\section{BEHAVIOR OF CERTAIN ANNUAL GRASSES}

Following the death of the perennial grasses during the first years of the drought, certain annual species became a veritable scourge. Chief among these were six-weeks fescue (Festuca octoflora), chess (Bromus secalinus or closely related species), and to a lesser extent little barley (Hordeum pusillum). These were nature's shock troops which held the bared soil from eroding until reclaimed by a more stable population. While Festuca is still plentiful in most droughtswept true prairies and Bromus and Hordeum in the western edge, yet none of these are now so continuous in the cover. As will be shown, the major bared or semi-bared areas have been so largely reclaimed by long-lived grasses or by certain native forbs that these annual grasses chiefly fill the smaller interspaces and are not found in large belts or patches as formerly.

\section{DECREASE OF RUDERALS}

The scourge of pepper grass (Lepidium virginicum and $L$. apetalum), so serious in 1936 and 1937 from the Missouri River to the Rocky Mountains, was not in evidence in true prairie during the past year of abundant rainfall. The horseweed (Leptilon canadense) likewise persisted in great abundance for only a year or two and has now practically disappeared from the native grassland. More local serious infections of goat's beard (Tragopogon pratensis) have now all but vanished. Indeed the absence of ruderals in all the true prairies, except a few where the vegetation was buried under drifting dust, was an outstanding characteristic, especially during 1938.

\section{RESPONSE OF CERTAIN NATIVE FORBS}

The chief native forbs that profited by the death of their competitors were Aster multiflorus, Erigeron ramosus, Solidago glaberrima, and (during the first years of drought only) two annuals, Silene antirrhina and Specularia perfoliata. The last two increased from a ranking of rare or infrequent to one of extreme abundance, populating the drought-bared areas everywhere.

Aster multiflorus, propagating both by seeds and very efficient rhizomes, became so extremely abundant as to ruin many of the prairies or large portions of them for the production of hay (figs. 4, 
5). In fact, during $1935^{-}-36$ it appeared that this forb would completely dominate the prairie. As a result considerable native sod was
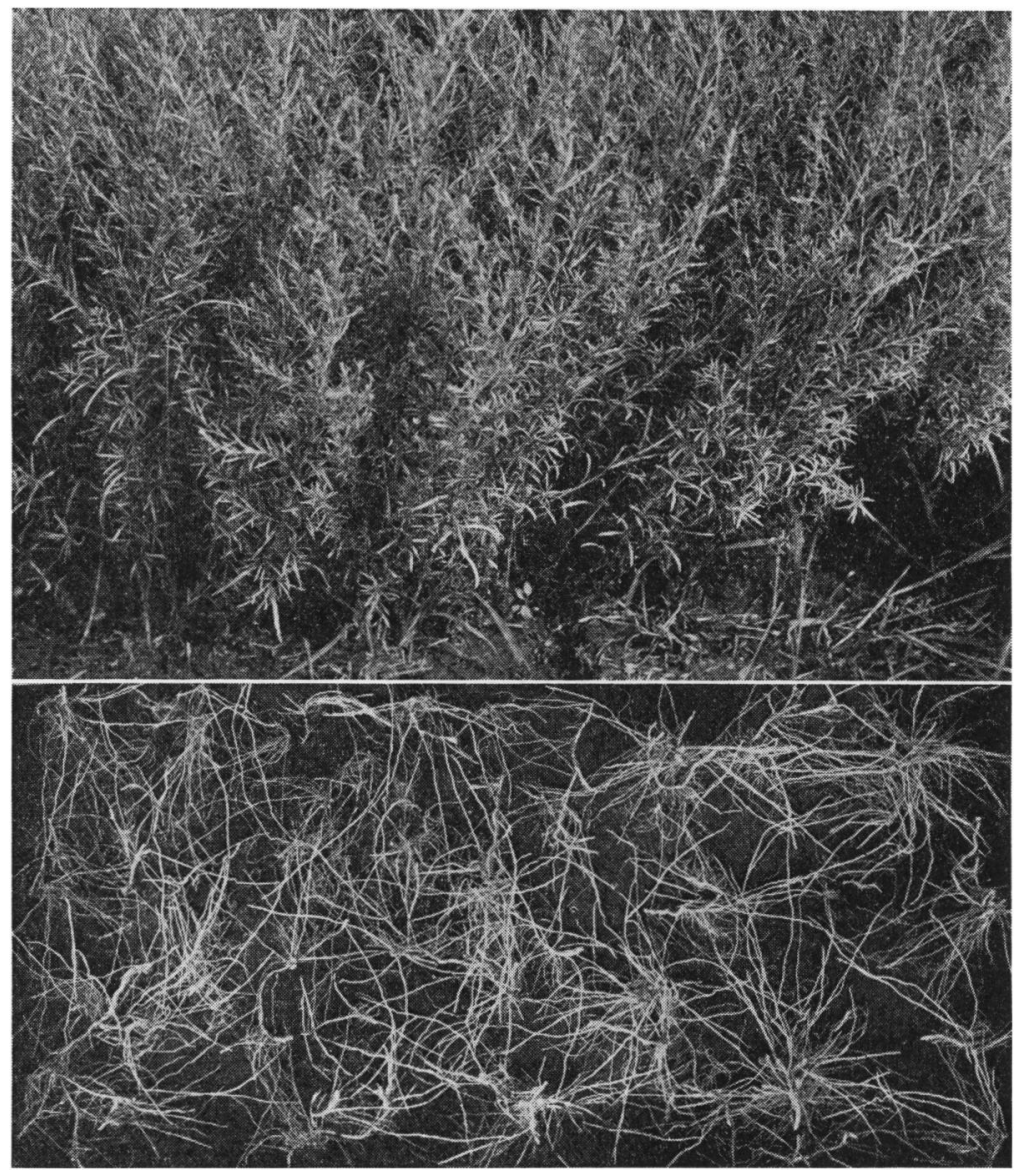

Figs. 4, 5.-Fig. 4, edge of dense patch of Aster multiflorus about 2 feet tall. Fig. 5, roots and rhizomes of Aster obtained by washing away the soil of one-half square meter area to depth of $10 \mathrm{~cm}$. Photographed Lincoln, Neb., July $25,1938$.

broken because of the seriousness of this pest. Plants with fifty or more woody stems with a spread of tops of 2.5 feet arose from a soil area of one-fourth square foot. Because of the low light intensity (often only I to 5 per cent of full sunshine at noonday), seedlings 
grew with difficulty, and relict grasses, if present, were greatly attenuated. While Aster is still important in occupying many local areas in nearly pure stands, it is plainly waning. In semi-sodded areas a more open type prevails, that is, one to four stems in a place separated from others by rhizomes 2 to 6 inches long. Thus it approaches more nearly its pre-drought condition, where it ranked in general as the third most important upland forb. There was a great decrease in both size and abundance of this forb in 1937, and markedly so in 1938 .

The enormous increase of Erigeron ramosus in most of the trueprairie areas is one of the outstanding features of the drought period. Always of high rank and great abundance, this typically short-lived biennial thrived in bare areas everywhere. Not only were the plants abundant but also often of greatly increased stature. Profiting by the numerous interspaces between the remaining bunches and mats of grasses, in eastern Nebraska especially, they offered a profusion of blossoms which at a distance appeared as newly fallen snow. Erigeron as a forb released from competition and persisting through the drought is an impressive phenomenon. In many of the western true prairies this species scarcely occurs.

Solidago glaberrima has increased greatly in many prairies, and its abundance is revealed especially in July with the yellowing of the inflorescence. One can easily anticipate the degree to which the grasses have been destroyed, that is, the bareness of the soil beneath, by observing the density of the stand of goldenrod.

It is of interest that, in the prairies of Iowa, where the losses by death were much smaller, in general, replacement was not by invading ruderals but by shiftings in the prairie populations. Increase of certain forbs, notably the rhizomatous Coreopsis palmata and to a less extent Aster multiflorus, was marked. The xeric grass, Sporobolus heterolepis, also made gains.

\section{RESPONSE OF CERTAIN FORBS WITH LARGE STORAGE ORGANS}

A remarkable increase of certain species, formerly of little importance, in the bared areas has occurred during the last two years. Their wide distribution and dense aggregation were most marked during the moist spring and early summer of 1938. All are char- 
acterized by some type of underground storage. In approximate order of abundance, the most important were Oxalis violacea, Senecio plattensis, Tradescantia bracteata, T. occidentalis, and Delphinium virescens. Allium mulabile, Anemone caroliniana, and Erythronium mesochoreum were also unusually abundant during the drought, although more locally distributed than the preceding. Oxalis formed

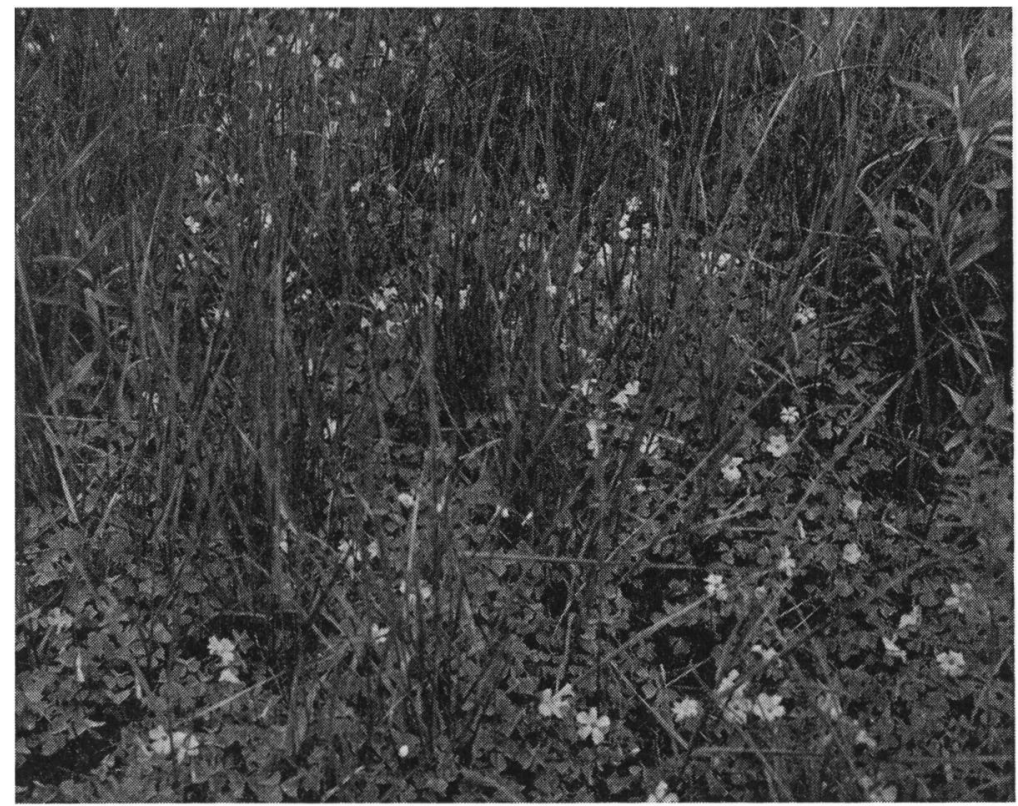

FIG. 6.-Oxalis violacea and Agropyron smithii invading drought-bared area. Photographed Crete, Neb., May 22, 1938.

dense patches, usually a few square feet or square yards in area, but such communities were widely distributed in most of the prairies studied (fig. 6). The somewhat fleshy rooted Senecio, formerly occurring as scattered individuals or small groups, increased manyfold and was a most conspicuous feature of the vernal aspect. Great groups of the fleshy rooted spiderwort occupied bared areas or were interspersed in the open places between the widely spaced bunch grasses. The thick-rooted larkspur had increased greatly in abundance and in places these usually solitary plants were rather closely 
grouped. These species, like the wild onion, wind flower, and dog's tooth violet, had all been favored by a marked decrease in the competition of other prairie components.

\section{INCREASE OF WHEAT GRASS AND CERTAIN OTHER XERIC GRASSES}

The great losses sustained by Andropogon scoparius, Poa pratensis, and other species made possible the enormous increase of more drought-resistant, competing species as well as great invasions by Agropyron smithii. The latter phenomenon was by far the most striking feature of the drastic modifications of the prairie.

Extensive earlier surveys showed clearly that western wheat grass, although a dominant of other portions of the true prairie, notably the. hardlands of the Dakotas, constituted scarcely any part of this association in the central prairie region. It occurred along roadways, occupied the compacted soil by the sides of trails through the prairie, and was found in abundance locally where a shallow claypan made conditions unfavorable for the growth of the usual dominants. Occasionally a few stems were found about disturbances such as gopher mounds. In native pastures, centers of infestation often occurred on knolls or about gateways where cattle or horses congregated and trampled the soil while stamping to free themselves of flies.

Immediately after 1934, wheat grass became increasingly abundant in both pastures and prairies. During the drought years it has continued spreading over all types of terrain, until today it is often the most important species in many prairies to within 40 miles of the Missouri River. Large circular areas where other species are practically absent indicate the excellent and rapid method of migrating by long, much branched rhizomes. Long narrow belts of wheat grass around the brows of hills indicate where early drought was most severe. Often whole hillsides are covered with pure stands of this grass, and many lowlands are a continuous area of undulating wheat-grass stems. Westward, grasslands hundreds of acres in extent have been three-fourths claimed by this species, and near Lincoln, Nebraska, similar extensive invasions of former bluestem prairies are easily found. Alternes or mixtures occur, but more often the stand is nearly pure. With often a thousand stems per square 
meter and a height of 3 to 3.5 feet, this expanse of grassland is an impressive sight (fig. 7). Studies along the invading fronts and the thinning of the stands in some areas with an increase in former dominants give some evidence of a decrease of this rapid spread. But should drought years continue, wheat grass may become even more extensive.

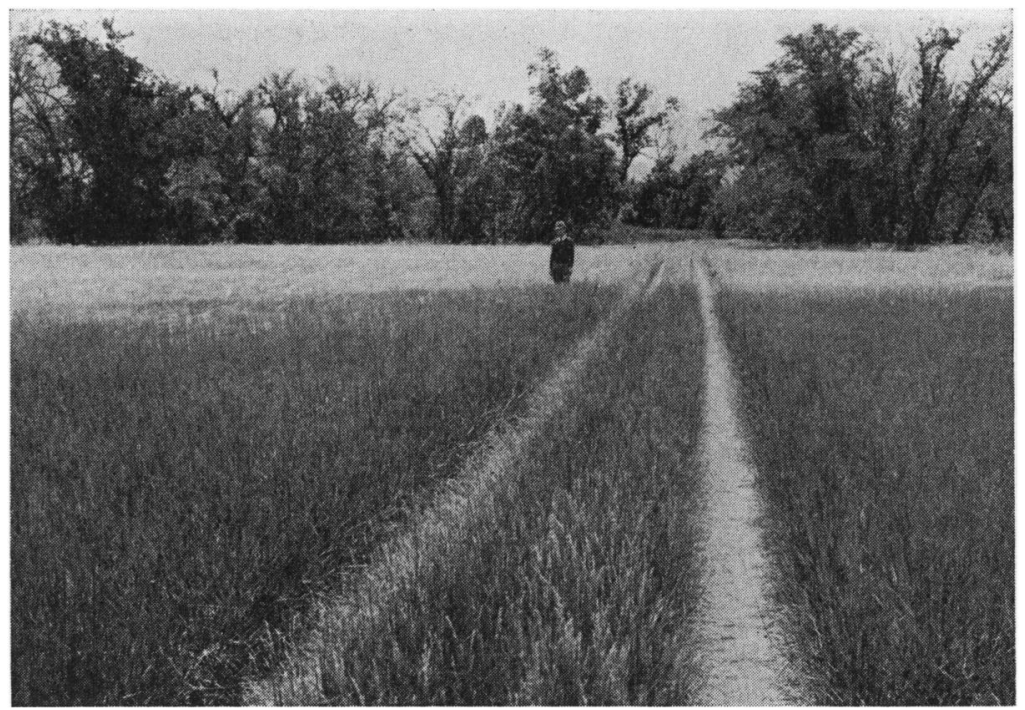

FIG. 7.-Complete disappearance of Andropogon and invasion by Agropyron smithii (dark) near Jamaica, Neb. Belt of bluestems 2 to 5 rods wide borders postclimax forest along the stream for 80 rods, where it was protected from the hot, dry winds.

Stipa spartea, although at first retarded, has greatly profited by the drought. Its spread has increased enormously and many new centers have been established. This change has been most pronounced in prairies of eastern Nebraska, where invasion by wheat grass has not occurred or has been less extensive. At Nebraska City, for example, a great ridge extends northeastward across a I60-acre prairie. In 1928 , only the northern crest of the ridge was dominated by Stipa, although it occurred as a species of much less importance than the bluestems along the entire ridge and extended also over the upper slopes. The early death of little bluestem was later followed by great losses of the more deeply rooted big bluestem. 
Death of the andropogons, forbs, etc., proceeded gradually down the slopes and the area is now claimed by needle grass. A community of Stipa of great extent, with the single dominant furnishing 90 to 98 per cent of the cover of grasses, extends continuously along the crest and spreads far down the slopes. Only near the foot of the hills does one find the bluestems well intact and seriously resisting the down-

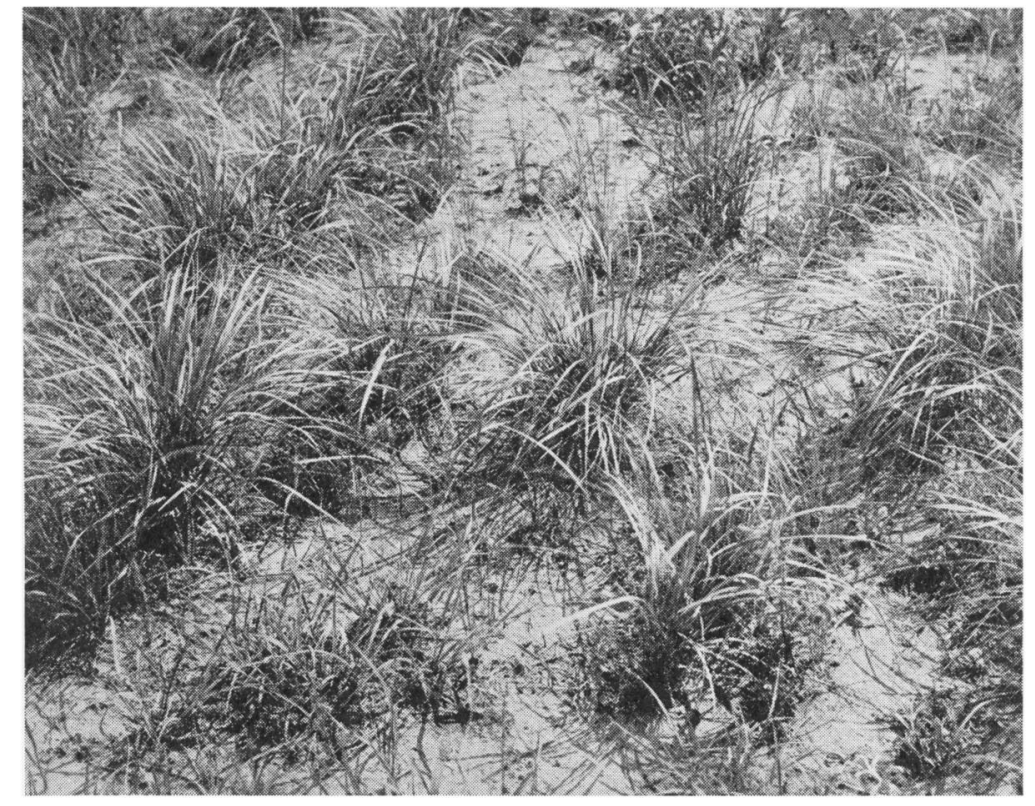

Fig. 8.- Open stand of Stipa spartea exposing much bare ground. Large portions of these bare areas recently reclaimed by seedlings of this species. Photographed June, I937.

ward spread of needle grass (fig. 8). Had one not known the composition of the previous cover, the invasion still is clearly evident. Everywhere the cover is open and the soil bare. Only relatively few of the bunches of Stipa are large; most are young, small, and widely spaced. Seedlings of needle grass with only a few stems are everywhere, but they are firmly established and only the single stemmed new seedlings may succumb. As many as fifty to sixty small bunches of Stipa, one or two large ones, and numerous seedlings are common in a square meter. Similar although less extensive spreading of Stipa has been recorded elsewhere. 
Prairie dropseed (Sporobolus heterolepis) is another xeric species that has spread considerably, especially in eastern Nebraska and western Iowa. In a few prairies it has become the ranking dominant; in many others its importance has greatly increased. S. asper has likewise become far more common and sometimes very abundant since the advent of the drought.

There has been a great spreading of the preclimax areas of short grasses. Buchloe dactyloides, with the death of its mid-grass competitors, has spread widely along the western fringe of true prairie and Bouteloua gracilis wherever it formerly existed, even if in small amounts. The latter was always of greater abundance in uplands and is somewhat more xeric. Increases in area of ten to fifteenfold have been recorded and new outposts have been established in many places. Carex pennsylvanica, which is similar in stature to short grasses, has likewise shown marked increases in many prairies and has greatly augmented its importance in pastures.

A grass that formerly occurred sparingly in almost all types of prairie but never attained complete local dominance is side-oats grama (Bouteloua curtipendula). During the years of drought it has spread widely until now it is one of the more important of prairie species. It has often persisted where all other grasses succumbed. Its remarkable increase has been due in part to its prolific seeding habit and in part to propagation by rhizomes. In many places it has largely replaced the losses occasioned by the death of little bluestem. In certain southwestern true prairies it has filled in locally bared areas with a pure stand. The bunches are often remarkably large, 6 or more inches in diameter, and the rhizomes 2 to 5 inches long. Elsewhere it often forms half or even more of the prairie cover. Thus the prairie patterns have changed in a most remarkable manner.

\section{REDUCTION OF BASAL COVER, LOSS OF LOWER LAYER AND BARENESS OF SOIL}

The great reduction of the basal cover of the prairies generally, except in those relatively small areas where even continued drought left the former prairie carpet intact, is of wide occurrence. It has been a process of eliminating species less fitted to withstand drought, younger plants not yet deeply rooted, and (probably) less vigorous 
individuals. From well distributed quadrats, plot estimates, and extensive observations, it has been determined that in general there has been a decrease of basal cover in most drought-stricken areas of 50 to 66 per cent. Small bare areas of one-half to one square foot occur regularly, while larger ones of I to I5 square meters with a basal

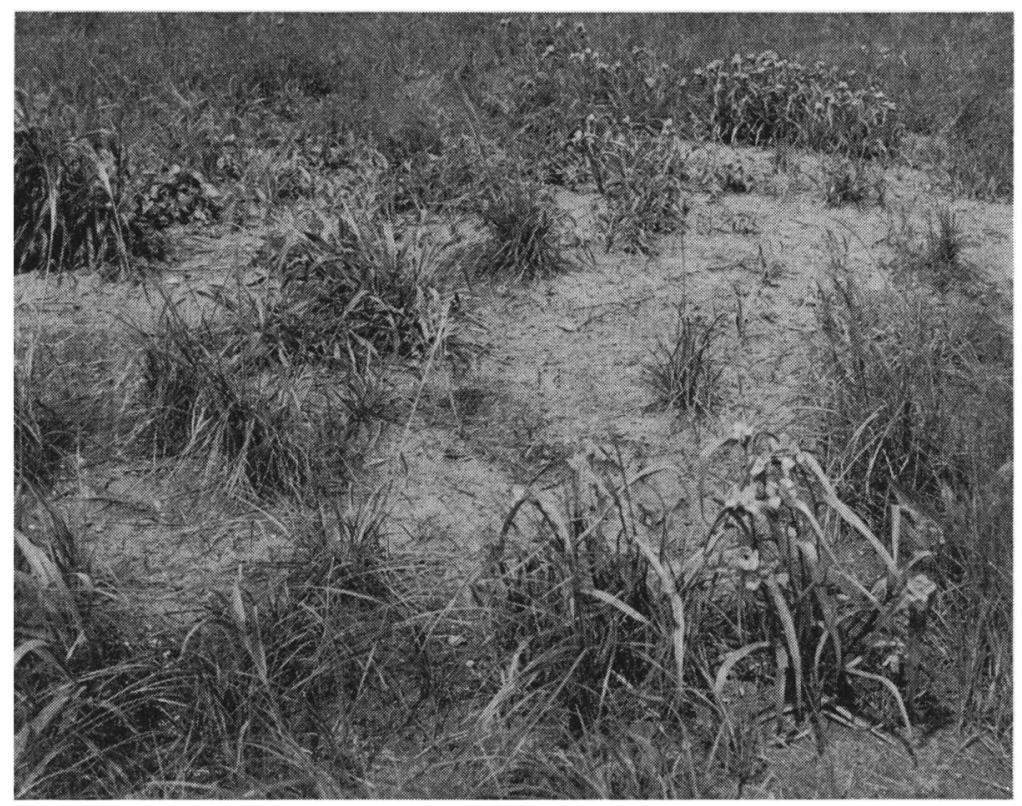

FIG. 9.-Representative bare area caused by continued years of drought. A few of the grasses (Andropogon) remained alive; others (Elymus canadensis, Panicum scribnerianum) are invaders. The forb is Tradescantia bracteata. Photographed May 22, 1938 .

cover of only I per cent are frequent (fig. 9). Where early summer rains were abundant, this wide spacing permitted an excellent growth of foliage. The bunch or sod was filled with stems; the foliage had spread widely. Each species alone produced enough seed to reclaim the entire area. Such a rank growth affords a foliage cover of 70 to 100 per cent. From the same base it may be only 30 to 50 per cent during a dry season. Hence one may be misled and believe that recovery has progressed far beyond the real state. Actually there is room for invasion almost everywhere. 
One who knows the prairies of old is constantly impressed with the bareness of the soil. The rank growth of a well developed threelayered vegetation is no more. The ground layer of mosses, lichens, Antennaria campestris, low species of Panicum, Viola, Astragalus crassicarpus, and tufts of $P o a$ has practically disappeared. Nor is the soil clothed with the former mulch of fallen leaves, flower parts, stems, etc. Much less of this material has been formed; the lack of moisture and abundance of direct sunshine and wind have caused it to wither and dry or often to blow away, leaving the black soil quite bare. Exceptions are the areas thickly sown by the wind to Festuca octoflora, etc., where the stems, lodged, dead, and dried by midsummer, protect the bare soil from sun, wind, and flood.

Both crowns and roots of the dead grasses decayed slowly because of the arid conditions. But after a few years an unusual abundance of dead organic material filled the prairie soil. This promoted the growth of numerous fungi, among which the red stinkhorn (Simblum sphaerocephalum) was most abundant and important. During the moist spring and early summer of 1938 this species was found widely and usually thickly distributed in nearly all the prairies. Ten or more individuals per square meter were not uncommon on low ground, and often the air was foul with the nauseating odor produced by this saprophyte.

\section{MODIFICATION OF GRASSLAND PATTERNS}

Still another drought feature of the landscape is the sharpness of the alternes marked off as a result of the great destruction, readjustments, and invasions. Here a deep soil area is so located that it escaped the full force of the oven-hot wind; vegetation remained intact. A pace beyond death has struck and Stipa or Sporobolus has spread to claim the area, or Koeleria has repopulated it, or perhaps Agropyron is in complete possession. The front and flanks of the mass movement of the latter can clearly be traced usually to within I meter, for great distances. Or one may in a step or two pass from pure stands of Andropogon furcatus into those of Bouteloua curtipen$d u l a$ or even $B$. gracilis. Large circular or irregular areas temporarily dominated by Aster or Erigeron give way abruptly to a fine growth of Andropogon furcatus, or patches of pure Festuca alternate with 
bare places, as if nature could not in such extremity reseed the whole bare surface. Such sharp transitions are remarkably different from the former intimate intermixtures of climax dominants and the broad ecotones separating the several types. Some of these remain, of course, but in general the change is outstanding.

\section{SignS OF RECOVERY}

The past year has witnessed an enormous crop of seedlings scattered widely, throughout the prairies. Prominent among these have been the grasses. Bouteloua curtipendula, B. gracilis, Panicum scribnerianum, Andropogon furcatus, Koeleria cristata, and Stipa spartea were especially well represented. Seedlings of Erigeron ramosus, Aster multiflorus, and Senecio plattensis ranked highest among the forbs, although a good population of various species of Psoralea, Liatris, Kuhnia, and others was found. Moreover, the few survivors among species of the lower layer are reviving and spreading gradually. Mat plants, bluegrass, and other low-growing forbs and grasses are beginning to reconstruct this layer next to the soil. A few prairies in certain sections favored by two consecutive years of good rainfall are started toward recovery. Although late summer drought destroyed much of the new seedling population, some survived, and with the enormous seed crop of the current year they will repopulate the bared areas if and when good rains prevail.

\section{Summary}

I. As a result of the great drought of 1934-37, the most important upland dominant, Andropogon scoparius, has suffered great destruction in the southern half of Nebraska.

2. The more deeply rooted Andropogon furcatus persisted during the early years of drought but has since suffered heavy losses.

3. Poa pratensis was nearly all killed in bluegrass pastures and only relatively small amounts remain in prairies.

4. Most species of forbs, including those very deeply rooted, have gradually succumbed to the continued drought, until they are only one-half to one-third of their former abundance.

5. Festuca octoflora, Bromus secalinus, and other annual grasses, which became extremely abundant after 1934, have now greatly 
decreased in quantity, filling the smaller interspaces rather than occupying large areas.

6. The scourge of the ruderal, Lepidium virginicum, so serious in 1936-37, has distinctly disappeared. Other annual weeds were extremely abundant only during one or two seasons.

7. The perennial, rhizomatous Aster multiflorus spread so widely into drought-bared areas as to ruin many prairies for production of hay. Erigeron ramosus was almost equally widespread.

8. A remarkable increase in abundance of Oxalis violacea, Allium mutabile, Tradescantia bracteata, and other species with thick roots or other storage organs has recently occurred.

9. Agropyron smithii, occurring sparsely at the beginning of the drought, has spread so widely as to cover one-half to three-fourths of the area of many former bluestem prairies.

Io. Marked increases in territory dominated by Stipa spartea and Sporobolus heterolepis have appeared. Bouteloua gracilis and Buchloe dactyloides have greatly increased. Bouteloua curtipendula, a dominant, formerly of relatively low rank, has now become one of the most important prairie grasses.

I I. Drought has reduced the basal cover in true prairie 50 to 66 per cent. The lower layer of grasses and forbs has been almost destroyed. Grassland types have been much modified.

UNIVERSITY OF NEBRASKA

LINCOLN, NEBRASKA

\section{LITERATURE CITED}

I. Weaver, J. E., and Albertson, F. W., Effects of the great drought on the prairies of Iowa, Nebraska, and Kansas. Ecology 17:567-639. 1936.

2. Weaver, J. E., and Fitzpatrick, T. J., The prairie. Ecol. Monog. 4:Io9295. I934.

3. Weaver, J. E., Stoddart, L. A., and Noll, W., Response of the prairie to the great drought of 1934. Ecology 16:61 2-629. I935. 